UDC 378.147:36-051

DOI: $10.31470 / 2415-3729-2018-8-182-196$

\title{
Fundamentalization of the Social Workers' Professional Training in the Context of Globalization Processes
}

\author{
Vira Polishchuk \\ Doctor in Pedagogy, Professor \\ Department of Social Pedagogy and Social Work \\ Ternopil Volodymyr Hnatiuk National Pedagogical University, \\ $\triangle$ 2, Maxyma Kryvonosa Str., Ternopil, Ukraine, 46027 \\ E-mail: polvira1951@gmail.com \\ ORCID: 0000-0002-4119-4329
}

\section{Фундаменталізація професійної підготовки соціальних працівників у контексті глобалізаційних процесів}

\section{Віра Аркадіївна Поліщук}

доктор педагогічних наук, професор

кафедра соціальної педагогіки і соціальної роботи

Тернопільський національний педагогічний університет

імені Володимира Гнатюка,

$\triangle$ вул. Максима Кривоноса, 2, м. Тернопіль, 46027

Дата надходження статті: 03 серпня 2018 р. Стаття прийнята до друку: 25 листопада 2018 р.

\begin{abstract}
The study is devoted to the problem of fundamentalization of the social workers' professional training. The article substantiates the urgency of the fundamentalization of an educational system in general and a social education, in particular, connected with the necessity of forming the future specialist's holistic perception of the world, and, at the same time, the profound occupation of the profession in the


context of globalization challenges. The benefit of this study is that the main manifestations of the globalization of the sphere of education are outlined as: the emergence of a global market for educational services; the emergence of educational transnational corporations; the informatization of education; a convergence, which involves the merger and interpenetration of educational and social systems; an integration; the standardization of both educational systems and cultural values. It is noted by the author that the fundamentalization of the training of social workers takes place within the framework of modernization of social education systems characterized by decentralization of a social education management, the unification of the content of social workers' training, the intensification of interdisciplinary cooperation, the internationalization of education, the introduction of distance learning technologies, etc. According to the purpose of the article, the essential characteristic of the fundamentalisation of education and specialists' vocational training is outlined as that which provides for the transition from narrow specialized to fundamental and holistic knowledge, focused on the development of scientific forms of specialist's thinking, its general and professional culture, and a high level of adaptability. The author of the article also outlined general methodological approaches to the analysis of education fundamentalization (systemic, synergistic, humanistic, epistemological, competence, acmeological, comprehensive, activity, person-oriented), each of them allows identifying problems of a system of the fundamentalization of the social sphere workers' professional training, describing the ways and basic means of their solution. Moreover, it is also noted by the author that, under current conditions, the fundamentalization of education is one of the leading factors in improving its quality, the basis of professional mobility of a specialist.

Key words: social education, preparation of social workers, fundamentalism, globalization.

\section{References}

1. Bardus, I. O. (2016). Filosofski zasady kontseptsii fundamentalizatsii profesiinoi pidhotovky maibutnikh fakhivtsiv $\mathrm{u}$ haluzi informatsiinykh tekhnolohii [The philosophical principles on 
the concept of the fundamentalization of professional training of future specialists in the field of information technologies]. Problemy inzhenerno-pedahohichnoi osvity - Problems of engineering and pedagogical education. 52-53. 7-17 [in Ukrainian].

2. Honcharenko, S. U. (2008). Fundamentalizatsiia profesiinoi osvity yak dydaktychnyi pryntsyp [Fundamentalization of vocational education as didactic principle]. Teoriia $i$ praktyka upravlinnia sotsialnymy systemamy: filosofiia, psykholohiia, pedahohika, sotsiolohiia - The theory and practice of social systems management: philosophy, psychology, pedagogy, sociology, 2, 87-91 [in Ukrainian].

3. Horishna, N. (2007). Cuchasni tendentsii rozvytku sotsialnoi roboty ta pidhotovky sotsialnykh pratsivnykiv. [Modern trends in the development of social work and training of social workers]. Social Work and Education, 4(2), 8-22 [in Ukrainian].

4. Kamashev, S. V. \& Kosenko, T. S. (2012). Globalizatsiya obrazovaniya i «globalnoe obrazovanie» $\mathrm{v}$ sovremennom mire. [Globalization of education and «global education» in the modern world]. Filosofiia obrazovaniia - Philosophy of education. 6 (45). 124-132 [in Russian].

5. Rebukha, L. (2017). Polifunktsionalna diialnist sotsialnoho pratsivnyka yak skladova sutnosti sotsialnoi roboty [Social worker's polyfunctional activity as a component of the content of social work]. Molod i rynok - Youth and the market, 1, 55-59 [in Ukrainian].

6. Semerikov S. O., Teplytskyi I. O.

(2009).

Fundamentalizatsiia yak osnova rozvytku innovatsiinoi vyshchoi osvity [Fundamentalization as the basis for the development of innovative higher education]. Zbirnyk naukovykh prats Kam'ianets-Podilskoho natsionalnoho universytetu: Seriia pedahohichna - Collection of scientific works of Kamenets-Podilskyi National University: Pedagogical series, 15, 249-251 [in Ukrainian].

7. Sysoieva, S. O. (2008). Naukovi doslidzhennia yak rezultat tvorchoho poshuku i profesiinoi samorealizatsii pedahoha [Scientific research as a result of creative search and the teacher's professional self-realization]. In S. O. Sysoieva (Ed.). Tvorchist $i$ tekhnolohii $v$ naukovykh doslidzhenniakh neperervnoi profesiinoi osvity [Creativity and technologies in the research of continuing vocational education]. 7-12. Kyiv: KIM [in Ukrainian]. 
8. Chitalin, N. A. (2000). Fundamentalnoe professionalnoe obrazovanie. [Fundamental vocational education]. Fundamentalnoe obrazovanie - Fundamental education, 2, 11-15 [in Russian].

9. Blok, W. (2011). Social work: an international profession in national straitjackets. Journal of Social Intervention: Theory and Practice, 20(1), 118-122.

10. Lyons, K. (2017). Globalization and social work: International and local implications. British Journal of Social Work, 36(3), 365-380.

11. Sapir, A. (2006). Globalization and the reform of European social models. JCMS: Journal of Common Market Studies, 44(2), 369-390.

\section{Ветуп}

Важливою формою і водночас новітнім етапом у розвитку світової спільноти у останні десятиліття стає глобалізація. Глобалізацію можна вважати найзначимішим соціальним процесом, який має вплив на усі сфери життєдіяльності суспільства, в тому числі й соціальну. Інтерес до впливу глобалізаційних процесів на соціальну політику, теорію і практику соціальної роботи піднімається з метою аналізу викликів, які виникають внаслідок процесів глобалізації так і обговорення ризиків, які уже мають місце $\mathrm{i}$ можуть виникати внаслідок зростаючих тенденцій глобалізації і міграції негативних наслідків, які глобалізаційні процеси можуть мати для здоров'я і добробуту людей.

Глобалізація освіти, що розглядає, по суті, універсальність і цілісність в якості основних своїх принципів, створює сприятливе підгрунтя для синтезування різних аспектів гармонійного розвитку особистості в усіх сферах, зокрема, у професійній. Глобалізаційні процеси у сфері освіти характеризуються насамперед активною модернізацією систем професійної освіти відповідно до викликів часу, що супроводжується певними труднощами та проблемами, серед яких однією із найбільш значущих $є$ проблема фундаменталізації сучасної освіти, пов'язана 3 необхідністю формування у майбутнього фахівця цілісного сприйняття світу, й водночас, поглибленого володіння професією. Вирішення цієї 
проблеми можливе, на наш погляд, лише з урахуванням сутнісної діалогічності свідомості людини, iii орієнтації на поєднання цивілізаційного, особистісного та професійного досвіду. Сучасна фундаменталізація освіти пов'язана 3 iï некласичною етизацією й аксіологізацією, які в свою чергу безпосередньо пов'язані 3 засвоєнням цінностей ноосферного мислення i цілісного світогляду.

Вплив глобалізації на різні сфери життя суспільства та професійної діяльності аналізують у своїх працях Р. Бірюков (правова сфера), О. Войналович, С. Камашев (освітня сфера), Н. Горішна (соціальна сфера), I. Нартова (економічна сфера) та інші. Дослідженню педагогічних аспектів проблеми фундаменталізації професійної освіти присвячені наукові роботи Н. Бідюка, О. Бондаренка, С. Гончаренка, Л. Зоріна, Б. Камінського, С. Клепко, Т. Кобильника, Л. Пуховської, С. Сисоєвої, В. Стешенка, Я. Фруктової, О. Школи. Особливості фундаменталізації як провідного принципу сучасної системи освіти вивчають Г. Дудка, М. Ковтонюк, Ю. Панфілов, А. Субетто, В. Філіпов. Фундаменталізація освіти як умова підвищення якості професійної підготовки фахівців $є$ предметом наукового дискурсу у працях I. Бардус, Н. Глушенок, Б. Хорошун, С. Семерікова, О. Язвінської. Водночас потребують подальшого поглибленого аналізу змістові аспекти фундаменталізації професійної освіти фахівців різного профілю. У цьому контексті фундаменталізація соціальної освіти залишається малодослідженою проблемою, яка відкриває широкий простір для наукових розвідок.

Мета статті полягає у розкритті сутнісної характеристики фундаменталізації професійної підготовки майбутніх фахівців соціальної сфери у контексті глобалізаційних процесів.

\section{Матеріал і методи дослідження}

Для досягнення поставленої мети у ході дослідження застосовано загальнонаукові методи аналізу, синтезу, порівняння та узагальнення наукових публікацій, розміщених в електронних базах даних Google Scholar та Web of Science, на вітчизняних та закордонних веб-сайтах, присвячених питанням підготовки майбутніх соціальних працівників та зарубіжного досвіду соціальної освіти. 


\section{Результати та їх обговорення}

Глобалізація - якісно новий етап в історії розвитку людства, що характеризується тенденцією до зближення та інтернаціоналізації суспільного життя у різних сферах. Одним iз найважливіших інструментів, покликаних сприяти вирішенню проблем та труднощів, зумовлених глобалізаційними процесами, є освіта. Основними проявами глобалізації сфери освіти є: виникнення глобального ринку освітніх послуг; поява освітніх транснаціональних корпорацій; інформатизація освіти; конвергенція, що передбачає злиття і взаємопроникнення освітніх і суспільних систем; інтеграція; стандартизація як освітніх систем, так і культурних цінностей [4]. Дані тенденції власне й стали передумовами створення Болонського процесу, спрямованого на гармонізацію історично сформованих неоднорідних освітніх систем шляхом створення єдиних європейських стандартів для полегшення взаємодії, академічної мобільності у сфері вищої освіти.

Соціальна робота та соціальна освіта, будучи орієнтованими на конкретний національно-культурний контекст, в сучасних умовах також набувають ознак універсальності, оскільки у міжнародній теорії та практиці все більше утверджується думка, що соціальна робота - це професія, яка виконує у різних соціумах схожі завдання, розвивається у тих самих напрямах, використовує однакові методи втручання та спрямована на пошук шляхів вирішення споріднених проблем (Blok, 2011; Sapir, 2006).

Як зазначає Н. Горішна, глобалізаційні процеси зумовлюють необхідність модернізації різних сфер життєдіяльності, у тому числі, й сфери соціальної освіти. У багатьох країнах світу сьогодні відбуваються процеси модернізації систем професійної підготовки соціальних працівників, які у кожній країні мають свою соціокультурну специфіку, проте можна відзначити і певні спільні тенденції, до яких відносимо: децентралізацію управління соціальною освітою, уніфікацію змісту підготовки соціальних працівників, посилення міждисциплінарної взаємодії, свідченням якої $€$ впровадження програм подвійних спеціальностей, інтернаціоналізацію освіти, впровадження технологій дистанційного навчання тощо (Горішна, 2007; Lyons, 2017). 
Важливим орієнтиром у діяльності закладів вищої освіти, що здійснюють підготовку соціальних працівників, $€$ їхня спрямованість на формування у фахівців професійної компетентності, мобільності та конкурентоспроможності на ринку праці. Вирішити окреслену комплексну проблему i покликана фундаменталізація освітнього процесу, яка спрямовує навчання фахівців у русло самостійної й оперативної адаптації до мінливих соціальних умов на засадах творчої універсалізації загальнометодологічних знань, вмінь i унормованих навичок (Семеріков, Теплицький, 2009:340).

Концептуальне розуміння фундаменталізації освіти було сформульоване представниками «Римського клубу». У їхньому баченні фундаменталізація освіти означає необхідність переходу від «підтримуючої» до «випереджальної» інноваційної освіти, що в свою чергу передбачає сутнісну перебудову змісту та методики викладання у вищому навчальному закладі 3 орієнтацією на професійне майбутнє випускника, оскільки значна частина набутих упродовж навчання професійних знань за короткий період часу втрачають свою актуальність під впливом суспільних змін (Гончаренко, 2008).

С. Сисоєва наголошує на важливості фундаменталізації професійної підготовки, що докорінно змінює парадигму вищої освіти, потребує постійного оновлення змісту освіти та освоєння студентами сучасних інтегрованих технологій неперервного навчання для регенерації знань сучасного фахівця. При такому підході одним 3 напрямів фундаменталізації освіти є зближення галузей науки 3 навчальними дисциплінами, що робить необхідним подальше наповнення змісту навчальних курсів у відповідності до фундаментальних наук (Сисоєва, 2008).

Сутнісне значення фундаменталізації професійної підготовки фахівців слід вбачати у необхідності переходу від вузькоспеціалізованих до фундаментальних, цілісних знань про сучасний світ і місце людини в цьому світі, орієнтованих на розвиток наукових форм мислення фахівця, загальної i професійної культури, високого рівня адаптативності. За сучасних умов фундаменталізація освіти $є$ одним 3 провідних 
чинників підвищення ऑii якості, основою професійної мобільності спеціаліста.

Фундаменталізація вищої освіти - системне і комплексне збагачення навчального процесу фундаментальними знаннями i методами творчого мислення, виробленими фундаментальними науками. Такий підхід лежить в основі принципової можливості та практичної доцільності інтеграції гуманітарної, фундаментальної та професійної складових підготовки фахівця різного профілю, у тому числі й фахівця соціальної сфери. Незаперечним $є$ той факт, що сучасна освіта має відповідати світоглядним реаліям XXI ст., зокрема, вона має корелювати зі світоглядними імперативами сталого розвитку. 3 іншого боку неоціненною $\epsilon$ роль власне фундаменталізації освіти в забезпеченні сталого розвитку суспільства як найважливішого завдання сучасної освіти в усьому світі.

М. Читалін виокремлює три види фундаменталізації професійної підготовки, кожен 3 яких спрямований на досягнення різних цілей: загальний забезпечує загальнонаукову, методологічну та фундаментальну компоненти професійної підготовки, спрямованої на формування наукового світогляду, творчого потенціалу та засвоєння культурних надбань людства; особливий передбачає формування професійної культури; одиничний спрямовує освіту на становлення професійної культури та зростання професійної майстерності (Читалин, 2000).

Соціальну освіту можна розглядати як складну, ієрархічно взаємопов'язану систему, в якій сукупні процеси спрямовані на покращення результативності навчання. Фундаменталізація професійної підготовки майбутніх соціальних працівників збагачує зміст фахової освіти, надає йому наукового, системного, концептуального характеру; дозволяє випускнику конструктивно вирішувати базові професійні завдання різної складності відповідно до проблем та напрямів розвитку соціальної сфери. Головним же мотивом фундаменталізації освіти різного профілю, у баченні I. Бардус, $є$ відставання освітньої сфери від темпів суспільного розвитку, що є природнім процесом (Бардус, 2016:9).

Фундаменталізацію соціальної освіти слід розглядати крізь призму різних підходів: системного, синергетичного, 
гуманістичного,

гносеологічного,

компетентнісного, акмеологічного, комплексного, діяльнісного, особистісноорієнтованого тощо. Кожен $з$ цих загальнометодологічних підходів дозволяє виокремити проблеми системи фундаменталізації професійної підготовки фахівців соціальної сфери, окреслити шляхи та основні способи їхнього вирішення та цілісно спрогнозувати найбільшу ймовірність отримання майбутніми соціальними працівниками об'єктивних, професійно-значущих знань, вмінь та навичок (Ребуха, 2017).

Під фундаменталізацією соціальної освіти також розуміють активну діяльність суб’єктів освітнього процесу, що спрямована як власне на фундаменталізацію змісту освіти, так і на гуманізацію освітнього процесу. Відповідно до гуманістичної парадигми основними цілями фундаменталізації освіти є формування:

1) універсальних та інваріантних (щодо технологій, конкретних деталей, думки людей тощо) елементів культури особистості, що забезпечують якісно новий рівень ii творчоінтелектуальної та емоційно-моральної культури, що сприяють швидкій адаптації фахівця до мінливих економічних та інформаційно-технологічних умов;

2) базових i системоутворюючих знань i умінь, що забезпечують взаємозв'язок i взаємодію елементів освітнього процесу, на основі яких можна самостійно знаходити і приймати відповідальні рішення в умовах невизначених, критичних i стресових ситуаціях, коли людина стикається 3 новими, складними соціальними проблемами;

3) цілісної гуманітарної та природничо-наукової освіти для усвідомлення законів природи i суспільства, створення єдиної світоглядної системи, заснованої на фундаментальних принципах сучасної методології;

4) оптимального інтелектуального середовища для розвитку узагальнених способів мислення і діяльності, вміння думати i самостійно здобувати знання, для розвитку гнучкого i багатогранного мислення того, хто навчається, для збагачення власного внутрішнього світу особистості, для формування внутрішньої потреби в саморозвитку та самоосвіті упродовж усього життя; 
5) умінь взаємодіяти 3 інформаційним середовищем, при якому відбувається наповнення навчально-пізнавальної діяльності особистісним змістом, коли індивід розглядає навчальне середовище як джерело збагачення власного внутрішнього світу, завдяки чому набуває компетентності та підсилює потенціал самого середовища;

6) готовності майбутнього фахівця застосовувати свої знання і вміння у стандартних та нестандартних професійних ситуаціях.

На думку С. Гончаренка, фундаменталізація професійної підготовки майбутніх фахівців спрямована на засвоєння універсальних, методологічно виважених знань, які формують загальну культуру особистості й позитивно впливають на розвиток наукового та професійного мислення. При цьому необхідність i значення фундаменталізації професійної освіти в умовах глобалізації зумовлюють такі положення: фундаменталізація професійної освіти, в тому числі іiі загальнонаукового (базового) компоненту, необхідна насамперед для гармонійної адаптації особистості до нових соціальних, економічних, технологічних i природних умов; фундаменталізація $є$ умовою суттєвого підвищення професійної мобільності особистості, оскільки розширює простір як для зміни професії в цілому, так i для професійних функцій і можливостей в рамках основної професії; фундаменталізація $\epsilon$ способом вирішення суперечності між зростаючим обсягом інформації (в тому числі й навчальної), та обмеженими можливостями ii засвоєння індивідом; фундаменталізація забезпечує перехід від концепції «освіти на все життя» до концепції неперервної освіти, «освіти упродовж життя» тощо (Гончаренко, 2008).

Відповідно до окресленої змістовної сутності фундаменталізація професійної підготовки майбутніх соціальних працівників здійснюється через такі іiі напрями: формування універсальних, базових знань про сутність і завдання соціальної діяльності; реалізація концептуальних цілей гуманізації та гуманітаризації освітнього процесу шляхом формування практикоорієнтованих цінностей згідно фаху, оновлення змісту навчання, наповнення його інноваційними знаннями та технологіями 
як інструментом донесення актуальних, затребуваних знань; навчально-методичне забезпечення професійної підготовки відповідно до вимог часу тощо.

Можемо стверджувати, що фундаменталізація соціальної освіти на сучасному етапі характеризується тяжінням до розширення функціонального поля соціальної роботи, посилення міждисциплінарних зв'язків, інтегрованим підходом до застосування педагогічних технологій професійної підготовки, спрямованих на формування компетентного фахівця, впровадженням загальнометодологічних наукових підходів для оперативного реагування на нові соціальні процеси та явища, i, як наслідок, проектування змісту фахової підготовки майбутніх соціальних працівників.

\section{Висновки}

В умовах модернізації соціальної освіти особливу увагу слід звернути на те, що фундаменталізація освіти має бути спрямована на підготовку фахівців, здатних на основі основоположних i системоутворюючих знань самостійно знаходити i приймати відповідальні рішення в умовах невизначеності, в критичних стресових ситуаціях, коли людина стикається з новими, складними природними i соціальними проблемами. Розуміння традицій i тенденцій фундаменталізації освіти, особливостей цього процесу на сучасному етапі розвитку суспільства дозволяє удосконалювати систему професійної підготовки соціальних працівників 3 урахуванням нових вимог часу, не відмовляючись при цьому від уже накопиченого вітчизняного позитивного досвіду соціальної освіти. В умовах, коли щойно сформовані знання випускників часто виявлються незатребуваними через високий темп мінливості соціально-економічних, інформаційно-технологічних характеристик суспільства, соціальна освіта має бути спрямована на забезпечення майбутніх фахівців фундаментальними знаннями, які є гарантією професійної мобільності, конкурентоспроможності, швидкої адаптації до нових вимог професії.

\section{Література \\ 1. Бардус I. O. Філософські засади концепції фундаменталізації професійної підготовки майбутніх фахівців}


у галузі інформаційних технологій. Проблеми інженернопедагогічної освіти. зб.наук. праць. Вип. 52-53. Харків: Українська інженерно-педагогічна академія, 2016. С. 7-17.

2. Гончаренко С. У. Фундаменталізація професійної освіти як дидактичний принцип. Теорія $і$ практика управління сочіальними системами: філософія, психологія, педагогіка, соиіологія. 2008. № 2. С. 87-91.

3. Горішна Н. Сучасні тенденції розвитку соціальної роботи та підготовки соціальних працівників. Social Work and Education. 2007. 4 (2). C. 8-22.

4. Камашев С. В., Косенко Т. С. Глобализация образования и «глобальное образование» в современном мире. Философия образования. 2012. № 6 (45). С. 124-132.

5. Ребуха Л. Поліфункціональна діяльність соціального працівника як складова сутності соціальної роботи. Молодь $i$ ринок. 2017. № 1. С. 55-59.

6. Семеріков С. О., Теплицький I. О. Фундаменталізація як основа розвитку інноваційної вищої освіти. Збірник наукових праць Кам'янець-Подільського національного університету: Серія педагогічна / редкол.: П. С. Атаманчук (голова, наук. ред.) [та ін.]. Кам'янець-Подільський : Кам'янець-Подільський національний університет імені Івана Огієнка, 2009. Вип. 15: Управління якістю підготовки майбутніх учителів фізики та трудового навчання. С. 249-251.

7. Сисоєва С. О. Наукові дослідження як результат творчого пошуку і професійної самореалізації педагога. Творчість $i$ технології в наукових дослідженнях неперервної професійної освіти : наук. вид. / авт. колектив: С. П. Балашова, Н. П. Баловська, Л. І. Бондарєва [та ін.] ; за заг. ред. С. О. Сисоєвої ; АПН України, Ін-т пед. освіти і освіти дорослих. K.: KIM, 2008. C. 7-12.

8. Читалин Н. А. Фундаментальное профессиональное образование. Фундаментальное образование. 2000. № 2. С. 11-15.

9. Blok W. Social work: an international profession in national straitjackets. Journal of Social Intervention: Theory and Practice. 2011. № 20(1). P. 118-122. 
10. Lyons K. Globalization and social work: International and local implications. British Journal of Social Work. 2017. № 36(3). P. 365-380.

11. Sapir A. Globalization and the reform of European social models. JCMS: Journal of Common Market Studies. 2006. 44(2). P. 369-390.

\section{Поліщук В. А.}

\section{Фундаменталізація професійної підготовки соціальних працівників у контексті глобалізаційних процесів}

\section{Анотація}

У статті обгрунтовано необхідність фундаменталізації системи освіти в цілому та соціальної освіти, зокрема, пов'язаної 3 необхідністю формування у майбутнього фахівця цілісного сприйняття світу, й водночас, поглибленого володіння професією у контексті глобалізаційних викликів. Окреслено основні прояви глобалізації сфери освіти: виникнення глобального ринку освітніх послуг; поява освітніх транснаціональних корпорацій; інформатизація освіти; конвергенція, що передбачає злиття і взаємопроникнення освітніх і суспільних систем; інтеграція; стандартизація як освітніх систем, так і культурних цінностей. Зазначено, що фундаменталізація підготовки соціальних працівників відбувається в рамках модернізації систем соціальної освіти, яка характеризується децентралізацією управління соціальною освітою, уніфікацією змісту підготовки соціальних працівників, посиленням міждисциплінарної взаємодії, інтернаціоналізацією освіти, впровадженням технологій дистанційного навчання тощо. Розкрито сутнісну характеристику фундаменталізації освіти та професійної підготовки фахівців, яка передбачає перехід від вузькоспеціалізованих до фундаментальних, цілісних знань, орієнтованих на розвиток наукових форм мислення фахівця, загальної і професійної культури, високого рівня адаптативності. Окреслено загальнометодолігічні підходи до аналізу фундаменталізації освіти (системний, синергетичний, 
гуманістичний, гносеологічний, компетентнісний, акмеологічний, комплексний, діяльнісний, особистісно-орієнтований), кожен 3 яких дозволяє виокремити проблеми системи фундаменталізації професійної підготовки фахівців соціальної сфери, окреслити шляхи та основні способи їхнього вирішення. Зазначено, що за сучасних умов саме фундаменталізація освіти є одним 3 провідних чинників підвищення іiі якості, основою професійної мобільності спеціаліста.

Ключові слова: соціальна освіта, підготовка соціальних працівників, фундаменталізація, глобалізація.

\section{Полищук В. А.}

\section{Фундаментализация профессиональной підготовки соціальных работников в контексте глобализационных процессов}

\section{Аннотация}

В статье обоснована необходимость фундаментализации системы образования в целом и социального образования, в частности, что обусловлено необходимостью формирования у будущего специалиста целостного восприятия мира и углубленного овладения профессией в контексте глобализационных вызовов. Раскрыты основные прояления глобализации в сфере образования: возникновение глобального рынка образовательных услуг; функционирование образовательных транснациональных корпораций; информатизация образования; конвергенция, которая предвидит слияние и взаимопроникновение образовательных и общественных систем; интеграция; стандартизация как образовательной системы так и культурных ценностей. Отмечено, что фундаментализация подготовки социальных работников происходит в контексте модернизации системы социального образования, которая хаарактеризуется децентрализацией управления социальным образованим, унификацией содержания подготовки социальных работников, усилением междисциплинарного взаимодействия, интернационализацией образования, внедрением технологий дистанционного образования. Раскрыто содержательную характеристику фундаментализации 
образования и профессиональной подготовки специалистов, которая предвидит переход от узкоспециализированных до фундаментальных, целостных знаний, ориентированных на развитие научных форм мышления специалистов, общей и профессиональной культуры, высокого уровня мобильности. Раскрыты общеметодологические подходы к анализу фундаментализации образования (системный, синергетический, гуманистический, гносеологический, компетентносный, акмеологический, комплексный, деятельностный, личностнооринентированный), каждый из которых позволяет определить проблемы системы фундаментализации профессиональной подготовки специалистов социальной сферы, определить направления и способы их решения. Подчеркнуто, что в современных условиях фундаментализация образования является одним 3 приоритетных направлений повышения его качества, основой формирования профессиональной конкурнентноспособности и мобильности специалиста.

Ключевые слова: социальное образование, подготовка социальных работников, фундаментализация, глобализация. 